\title{
Mass Spectra of Deuteroacetylenes, Monodeuterobenzene, and Deuteronaphthalenes
}

\author{
Fred L. Mohler, Vernon H. Dibeler, Laura Williamson, and Helen Dean
}

\begin{abstract}
Mass spectra at 70-volt ionizing voltage have been measured for $\mathrm{C}_{2} \mathrm{H}_{2}, \mathrm{C}_{2} \mathrm{HD}, \mathrm{C}_{2} \mathrm{D}_{2}$, $\mathrm{C}_{6} \mathrm{H}_{6}, \mathrm{C}_{6} \mathrm{H}_{5} \mathrm{D}, \mathrm{C}_{10} \mathrm{H}_{8}, \mathrm{C}_{10} \mathrm{H}_{7} \mathrm{D}$, and for a mixture of $\mathrm{C}_{10} \mathrm{D}_{8}$ and $\mathrm{C}_{10} \mathrm{HD}_{7}$. In acetylene, benzene, and naphthalene it is possible to measure the isotopic purity at ionizing voltages below the appearance potential of any fragment ions and to correct the observed spectra of monodeutero compounds for isotopic impurity.

For $\mathrm{C}_{2} \mathrm{HD}$ the probability of removing the $\mathrm{H}$ atom is nearly twice as great as that of removing the $\mathrm{D}$ atom. In monodeutero benzene and naphthalene, on the other hand, there is no such selectivity, and it is possible to compute the spectra of the monodeutero compounds on the basis of equal a priori probability of removing a single $\mathrm{H}$ or $\mathrm{D}$ atom. By assuming that equal probability holds for doubly charged ions, the complete doubly charged ion spectra can be computed from the observed half-integer peaks. Similarly, the spectra of $\mathrm{C}_{10} \mathrm{D}_{8}$ and $\mathrm{C}_{10} \mathrm{HD}_{7}$ are computed from a spectrum of a mixture of the two compounds.
\end{abstract}

\section{Introduction}

There have been a number of papers published on the mass spectra of the simpler hydrocarbons containing one or more deuterium atoms $[1,2,3] .{ }^{1}$ In compounds containing both $\mathrm{D}$ and $\mathrm{H}$, the probability of removing $\mathrm{H}$ is greater and that of removing $\mathrm{D}$ is less than the probability of removing $\mathrm{H}$ in the hydrogen compound. Thus in $\mathrm{CH}_{3} \mathrm{D}$ [3], the probability of removing $\mathrm{H}$ is increased by a factor, 1.18, and that of removing $\mathrm{D}$ is decreased by a factor, 0.45 , as compared with the a priori probabilities of removing $\mathrm{H}$ or $\mathrm{D}$. In general, in compounds containing two or more carbon atoms with several $\mathrm{H}$ atoms on each carbon atom, it is impossible to predict what the spectrum will be when one deuterium atom is in a given position in the molecule.

This paper deals with three hydrocarbons containing only one $\mathrm{H}$ atom on each carbon atom. These spectra were studied in the expectation that they would be simpler to interpret than mass spectra of compounds containing several $\mathrm{H}$ atoms on each carbon atom.

Because the mass spectra of monodeutero hydrocarbons cannot be predicted, it is in general not feasible to measure the isotopic purity from the mass spectra obtained under standard conditions with 50or 70-v ionizing potential. Wagner and Stevenson [4] have pointed out that one can obtain a direct measurement of isotopic purity at an ionizing potential so low that only the molecule ions are produced. In most hydrocarbons this requires a potential within a volt or two of the first ionization potential, and the sensitivity is very low. However, in acetylene, benzene, and naphthalene the molecule ions are very stable, and 5 or $6 \mathrm{v}$ in excess of the first ionization potential are required to produce ions with one $\mathrm{H}$ atom removed. This permits an accurate measurement of isotopic purity and an unambiguous derivation of the monodeutero spectra of these compounds.

Mass spectra were measured with a model 21-102 Consolidated mass spectrometer, using standard

\footnotetext{
1 Figures in brackets indicate the literature references at the end of this paper.
}

operating conditions and an ionizing potential of $70 \mathrm{v}$ for the spectra tabulated. For the purity measurements at low ionizing potential, the ion drawout voltage was supplied by a battery instead of using the standard circuit.

\section{Deuteroacetylenes}

The authors have previously published mass spectra of deuteroacetylenes [5]. The measurements have been repeated, and the $\mathrm{C}_{2} \mathrm{HD}$ spectra are considered more accurate than before. $\mathrm{C}_{2} \mathrm{H}_{2}$ was made by the reaction of distilled water on commercial calcium carbide, and $\mathrm{C}_{2} \mathrm{D}_{2}$ was made by the reaction of $\mathrm{D}_{2} \mathrm{O}$ on calcium carbide. Commercial calcium carbide contains some calcium hydroxide from contact with atmospheric moisture, and this contaminates the $\mathrm{D}_{2} \mathrm{O}$ product gas with $\mathrm{C}_{2} \mathrm{HD}$. Prolonged baking of the carbide in a vacuum at $700^{\circ} \mathrm{C}$ reduced this contamination but did not eliminate it. The $\mathrm{C}_{2} \mathrm{D}_{2}$ contained 1.7 percent of $\mathrm{C}_{2} \mathrm{HD}$. The $\mathrm{C}_{2} \mathrm{HD}$ contribution was subtracted from the observed spectrum, using the pattern given in table 1 in the final approximation.

TABLE 1. Mass spectra of acetylenes a

\begin{tabular}{|c|c|c|c|c|c|}
\hline \multicolumn{2}{|c|}{$\mathrm{C}_{2} \mathrm{H}_{2}$} & \multicolumn{2}{|c|}{$\mathrm{C}_{2} \mathrm{HD}$} & \multicolumn{2}{|c|}{$\mathrm{C}_{2} \mathrm{D}_{2}$} \\
\hline Ion & $\begin{array}{l}\text { Relative } \\
\text { intensity }\end{array}$ & Ion & $\begin{array}{l}\text { Relative } \\
\text { intensity }\end{array}$ & Ion & $\begin{array}{l}\text { Relative } \\
\text { intensity }\end{array}$ \\
\hline $\mathrm{C}_{2} \mathrm{H}_{2}{ }^{+} \ldots$ & 100 & $\mathrm{C}_{2} \mathrm{HD}^{+} \ldots$ & 100 & $\mathrm{C}_{2} \mathrm{D}_{2}{ }^{+}-$ & 100 \\
\hline $\mathrm{C}_{2} \mathrm{H}^{+} \ldots$ & 23.0 & $\mathrm{C}_{2} \mathrm{H}^{+}$ & 7.67 & $\mathrm{C}_{2} \mathrm{D}^{+}$ & 19.9 \\
\hline $\mathrm{C}_{2}^{+} \ldots$ & 6. 99 & $\mathrm{C}_{2}+\ldots$ & 6.02 & $\mathrm{C}_{2}{ }^{+}$ & 5. 49 \\
\hline $\mathrm{CH}_{2}{ }^{+} \ldots$ & 0.34 & $\mathrm{CHD}^{+} \ldots$ & 0.28 & $\mathrm{CD}_{2}{ }^{+}$ & 0.25 \\
\hline $\mathrm{CH}^{+}$ & $(4.25)$ & $\mathrm{CH}^{+}$ & 1.86 & $\mathrm{CD}^{+}$ & (5. 75) \\
\hline $\mathrm{C}^{+} \ldots$ & 3.22 & $\mathrm{C}^{+} \ldots$ & 3. 09 & & 3.14 \\
\hline $\mathrm{C}_{2} \mathrm{H}_{2}++$ & $(2,70)$ & $\mathrm{C}_{2} \mathrm{HD}^{++}$ & 2.70 & $\mathrm{C}_{2} \mathrm{D}_{2}{ }^{++}$ & $(2.70)$ \\
\hline $\operatorname{Sum}_{\ldots}$ & 141 & 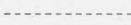 & 139 & - & 137 \\
\hline Sensitivity & 110 & & - & & 111 \\
\hline
\end{tabular}

a Values in parentheses are computed on the assumption that doubly charged ions give equal contributions in all three spectra.

$\mathrm{C}_{2} \mathrm{HD}$ was not made, but a mixture of acetylenes with about two parts of $\mathrm{D}_{2} \mathrm{O}$ and one part of $\mathrm{H}_{2} \mathrm{O}$ reacting with carbide was made. The relative 
amounts of $\mathrm{C}_{2} \mathrm{H}_{2}, \mathrm{C}_{2} \mathrm{HD}$, and $\mathrm{C}_{2} \mathrm{D}_{2}$ were measured at a voltage below the appearance potential of $\mathrm{C}_{2} \mathrm{D}^{+}$ from $\mathrm{C}_{2} \mathrm{HD}$ and $\mathrm{C}_{2} \mathrm{D}_{2}$. Kusch, Hustrulid, and Tate [6] give the appearance potentials of $\mathrm{C}_{2} \mathrm{H}_{2}{ }^{+}$and $\mathrm{C}_{2} \mathrm{H}^{+}$ as 11.2 and $17.8 \mathrm{v}$. It was verified that the appearance potentials of $\mathrm{C}_{2} \mathrm{H}_{2}{ }^{+}$and $\mathrm{C}_{2} \mathrm{D}_{2}{ }^{+}$are equal within experimental error and that the ionization efficiency curves are identical. The ionizing voltage was set just below the appearance potential of $\mathrm{C}_{2} \mathrm{H}^{+}$of $\mathrm{C}_{2} \mathrm{H}_{2}$ and $\mathrm{C}_{2} \mathrm{D}^{+}$of $\mathrm{C}_{2} \mathrm{D}_{2}$ and the ratios of the peaks of masses 26, 27, and 28 in the mixture were measured. The contributions of $\mathrm{C}_{2} \mathrm{H}_{2}$ and $\mathrm{C}_{2} \mathrm{D}_{2}$ were subtracted from the mixture spectrum, using the patterns given in table 1.

Table 1 gives the spectra of the three acetylenes at $70-\mathrm{v}$ ionizing potential with the contributions of $\mathrm{C}_{13}$ isotopes subtracted. These spectra are nearly identical with spectra previously published by two of the authors [5]. In the $\mathrm{C}_{2} \mathrm{HD}$ spectrum, the ion $\mathrm{C}_{2} \mathrm{HD}^{++}$ at $13 \frac{1}{2}$ is 2.70 percent of the maximum peak. It is assumed that in $\mathrm{C}_{2} \mathrm{H}_{2}$ and $\mathrm{C}_{2} \mathrm{D}_{2}$ doubly charged ions make an equal contribution to the peaks at $\mathrm{m} / \mathrm{e} 13$ and 14 , respectively, and 2.70 has been subtracted from the observed relative intensity to derive the values of $\mathrm{CH}^{+}$and $\mathrm{CD}^{+}$.

The relative intensities in the spectra of $\mathrm{C}_{2} \mathrm{H}_{2}$ and $\mathrm{C}_{2} \mathrm{D}_{2}$ are similar but not identical. The sensitivities (current per unit pressure) for the molecule ions are equal within experimental error, and the sum of the relative intensities of all the ions is slightly less in the deuterated compounds. Similar relations between hydrogen compounds and deuterium compounds are found in methane [3], ethane, and diborane [7].

In $\mathrm{C}_{2} \mathrm{HD}$ the a priori probabilities of removing $\mathrm{H}$ and $\mathrm{D}$ are equal, but the observed ratio $\mathrm{C}_{2} \mathrm{D}^{+} / \mathrm{C}_{2} \mathrm{H}^{+}$ is nearly 2 (accurately 1.92). The sum of the two peaks, 22.4, is intermediate between $\mathrm{C}_{2} \mathrm{H}^{+}$and $\mathrm{C}_{2} \mathrm{D}^{+}$ in the other two spectra. The ratio $\mathrm{CD}^{+} / \mathrm{CH}^{+}=$ 1.20 , and the sum of the relative intensities for the two ions, 4.14, is nearly equal to $\mathrm{CH}^{+}$of $\mathrm{C}_{2} \mathrm{H}_{2}$. Thus, when contributions of ions containing one D and one $\mathrm{H}$ are added, the whole spectrum becomes much like $\mathrm{C}_{2} \mathrm{H}_{2}$, and the sum of all the ions is nearly equal to the sum for $\mathrm{C}_{2} \mathrm{H}_{2}$. The sensitivities are also nearly equal, but the experimental uncertainty is rather large for $\mathrm{C}_{2} \mathrm{HD}$, as $\mathrm{C}_{2} \mathrm{HD}$ was less than a third of the mixture analyzed.

\section{Monodeuterobenzene}

$\mathrm{C}_{6} \mathrm{H}_{5} \mathrm{D}$ was made by a Grignard reaction, and an isotopic analysis of the product gas was made at low voltage. Hustrulid, Kusch, and Tate [8] found the appearance potentials to be $9.8 \mathrm{v}$ for $\mathrm{C}_{6} \mathrm{H}_{6}{ }^{+}$ and $14.5 \mathrm{v}$ for $\mathrm{C}_{6} \mathrm{H}_{5}{ }^{+}$. Using ordinary benzene, the ionizing voltage was set below the appearance potential of $\mathrm{C}_{6} \mathrm{H}_{5}{ }^{+}$. With this ionizing voltage the intensity of the 78 peak in the deuterated benzene relative to the 79 peak gives a sensitive measurement of the amount of $\mathrm{C}_{6} \mathrm{H}_{6}$ in the $\mathrm{C}_{6} \mathrm{H}_{5} \mathrm{D}$. The sample used contained 3.2 percent of $\mathrm{C}_{6} \mathrm{H}_{6}$ and 96.8 percent of $\mathrm{C}_{6} \mathrm{H}_{5} \mathrm{D}$, with no evidence of any other impurities. Column 3 of table 2 gives the spectrum of $\mathrm{C}_{6} \mathrm{H}_{5} \mathrm{D}$ at $70-\mathrm{v}$ ionizing voltage. This spectrum has been corrected for the contributions of $\mathrm{C}_{13}$ and $\mathrm{C}_{6} \mathrm{H}_{6}$ to the observed spectrum. Column 2 gives the $\mathrm{C}_{6} \mathrm{H}_{6}$ spectrum measured under similar conditions. Values marked with letter "a" are corrected for the contribution of doubly charged ions computed on a basis described later.

TABLE 2. Mass spectra of benzene and monodeuterobenzene Sensitivity relative to the 43 peak of $n$-butane ( 78 of $\mathrm{C}_{6} \mathrm{H}_{6}, 1.34 ; 79$ of $\mathrm{C}_{6} \mathrm{H}_{5} \mathrm{D}, 1.36$ ).

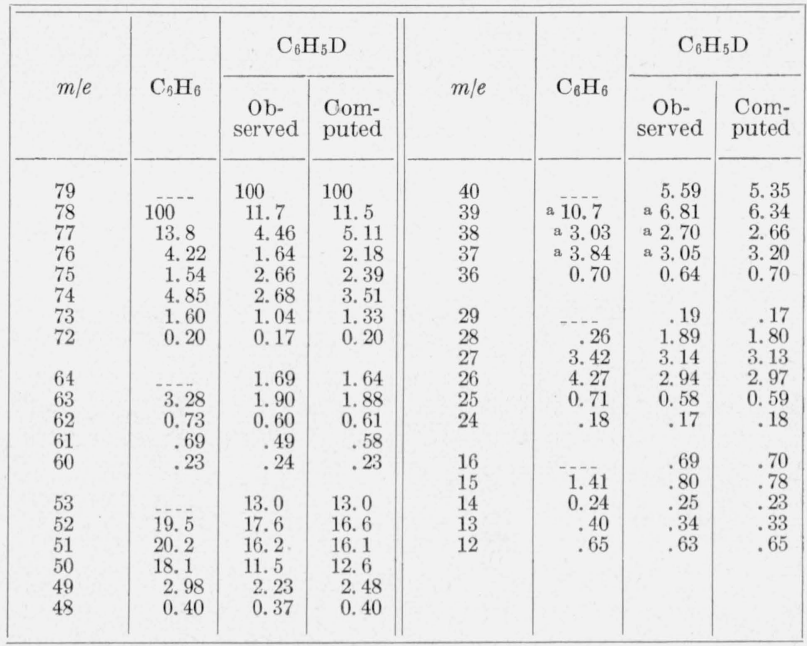

a Values corrected for doubly charged ions.

Column 4 of table 2 gives relative intensities computed from those of $\mathrm{C}_{6} \mathrm{H}_{6}$, on the assumption that there is equal probability of removing an $\mathrm{H}$ or D atom in forming a fragment ion. Thus, when one of six equivalent atoms is removed, as in forming $\mathrm{C}_{6} \mathrm{H}_{5}^{+}$from $\mathrm{C}_{6} \mathrm{H}_{6}$ or $\mathrm{C}_{6} \mathrm{H}_{5}^{+}$and $\mathrm{C}_{6} \mathrm{H}_{4} \mathrm{D}^{+}$from $\mathrm{C}_{6} \mathrm{H}_{5} \mathrm{D}$, the relative intensities on this assumption are $6: 1: 5$. The observed fact that the 78 peak $\left(\mathrm{C}_{6} \mathrm{H}_{4} \mathrm{D}^{+}\right)$of $\mathrm{C}_{6} \mathrm{H}_{5} \mathrm{D}$ is almost exactly $5 / 6$ of the 77 peak $\left(\mathrm{C}_{6} \mathrm{H}_{5}^{+}\right)$of $\mathrm{C}_{6} \mathrm{H}_{6}$ is a strong indication that the probabilities are equal. This is in marked contrast to the case of monodeutero acetylene, where the $\mathrm{C}_{2} \mathrm{D}^{+}$peak is nearly twice the $\mathrm{C}_{2} \mathrm{H}^{+}$ peak.

The remaining computed relative intensities in table 2 were obtained by extending the computation in a simple manner. When there are six equivalent atoms, one of which is $D$, the chance of removing $D$ is $1 / 6$, if one atom is removed; $2 / 6$, if two are removed; $3 / 6$, if three are removed, etc., and the chance of removing only $H$ 's is, of course, 1 minus the above fractions. These relations are assumed to hold when carbon-carbon bonds are broken, as well as when only $\mathrm{C}-\mathrm{H}$ bonds are broken.

In the $\mathrm{C}_{6} \mathrm{H}_{5} \mathrm{D}$ spectrum most of the peaks contain contributions from two ions. For example, at mass 77 there is $\mathrm{C}_{6} \mathrm{H}_{5}^{+}$(computed intensity $1 / 6 \times 13.8=2.30$ ), and $\mathrm{C}_{6} \mathrm{H}_{3} \mathrm{D}^{+}$(computed intensity $2 / 3 \times 4.22=2.87$ ), giving a total computed intensity of 5.11 as compared with 4.46 observed.

It will be noted in table 2 that the agreement 
of computed and observed intensities is least satisfactory for $\mathrm{C}_{6}$ ions containing one to four hydrogen atoms. However, in most of the benzene spectrum the observed $\mathrm{C}_{6} \mathrm{H}_{5} \mathrm{D}$ spectrum is in very satisfactory agreement with the computed spectrum. Peaks $28,27,15$, and 14 in the $\mathrm{C}_{6} \mathrm{H}_{6}$ spectrum, corresponding to ions $\mathrm{C}_{2} \mathrm{H}_{4}^{+}, \mathrm{C}_{2} \mathrm{H}_{3}^{+}, \mathrm{CH}_{3}^{+}$, and $\mathrm{CH}_{2}^{+}$, involve rearrangements of $\mathrm{H}$ atoms in the ionization process. The agreement between observed and computed intensities in the $\mathrm{C}_{6} \mathrm{H}_{5} \mathrm{D}$ spectrum is just as good in these cases as in cases where simple dissociation is involved.

The observed peaks 37,38 , and 39 in both $\mathrm{C}_{6} \mathrm{H}_{6}$ and $\mathrm{C}_{6} \mathrm{H}_{5} \mathrm{D}$ spectra contain contributions from doubly charged ions of mass 74, 76, and 78. Doubly charged ions of odd mass number give half-integer peaks and are observed, while ions of even mass number coincide with peaks of singly charged ions. On the basis of results in table 2 it seems safe to assume that doubly charged ions in the two spectra are also related by simple a priori probability considerations. If this is assumed, the observed half-integer peaks in the two spectra permit computations of the complete doubly charged ion spectra of both molecules.

The data are shown in table 3, where the values in parentheses are computed values. The $391 \frac{1}{2}$ peak of $\mathrm{C}_{6} \mathrm{H}_{5} \mathrm{D}$ is the doubly charged molecule ion, and it is assumed that in the $\mathrm{C}_{6} \mathrm{H}_{6}$ spectrum $\mathrm{C}_{6} \mathrm{H}_{6}^{++}$makes an equal contribution to the 39 peak. The $38 \frac{1}{2}$ peak of $\mathrm{C}_{6} \mathrm{H}_{6}$ is $\mathrm{C}_{6} \mathrm{H}_{5}^{++}$. The ion $\mathrm{C}_{6} \mathrm{H}_{4} \mathrm{D}^{++}$and $\mathrm{C}_{6} \mathrm{H}_{5}^{++}$of the monodeutero compound are assumed to be $5 / 6$ and $1 / 6$ of the first peak, or 0.31 and 0.06 . The $38 \frac{1}{2}$ peak of $\mathrm{C}_{6} \mathrm{H}_{5} \mathrm{D}$ is 1.79 , and it comes from $\mathrm{C}_{6} \mathrm{H}_{3} \mathrm{D}^{++}$and $\mathrm{C}_{6} \mathrm{H}_{5}^{++}$. Subtracting the computed value of $\mathrm{C}_{6} \mathrm{H}_{5}^{++}$ gives $\mathrm{C}_{6} \mathrm{H}_{3} \mathrm{D}^{++}$as 1.73 . $\mathrm{C}_{6} \mathrm{H}_{4}^{++}$of $\mathrm{C}_{6} \mathrm{H}_{5} \mathrm{D}$ will be $1 / 2$ of 1.73 , and $\mathrm{C}_{6} \mathrm{H}_{4}^{++}$of $\mathrm{C}_{6} \mathrm{H}_{6}$ will be $3 / 2$ of 1.73. Similarly, $\mathrm{C}_{6} \mathrm{H}_{3}^{++}$of $\mathrm{C}_{6} \mathrm{H}_{6}$ gives the $\mathrm{C}_{6} \mathrm{H}_{2} \mathrm{D}^{++}$ peak of $\mathrm{C}_{6} \mathrm{H}_{5} \mathrm{D}$, and the $\mathrm{C}_{6} \mathrm{HD}^{++}$peak of $\mathrm{C}_{6} \mathrm{H}_{5} \mathrm{D}$

TABLE 3. Doubly charged ions of $\mathrm{C}_{6} \mathrm{H}_{6}$ and $\mathrm{C}_{6} \mathrm{H}_{5} \mathrm{D}$

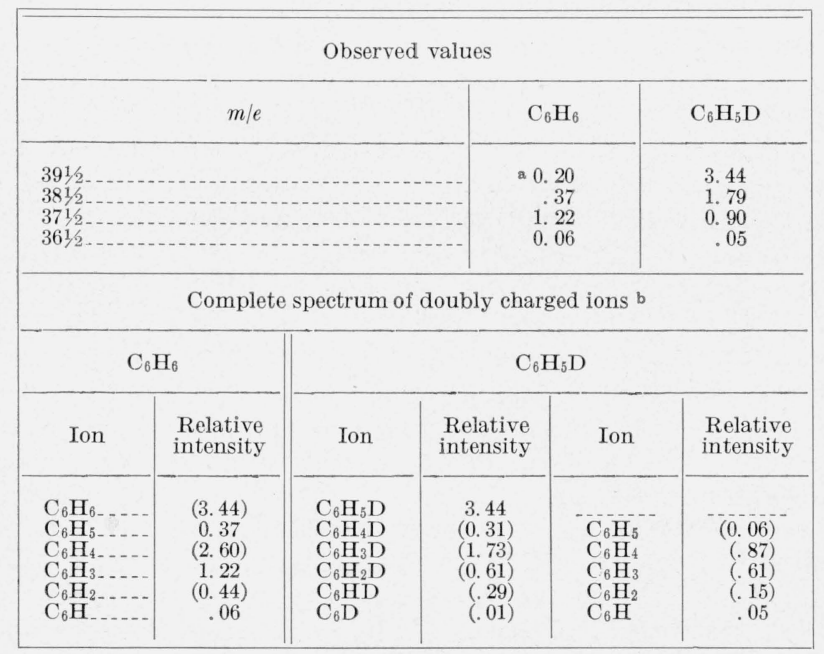

a This $\mathrm{C}_{6}^{13} \mathrm{H}_{6}^{++}$isotope peak indicates a value of 3.0 for $\mathrm{C}_{6}^{12} \mathrm{H}_{6}^{++}$.

b Values in parentheses are computed on the basis of a priori probabilities from the observed values. gives $\mathrm{C}_{6} \mathrm{H}_{2}^{++}$of $\mathrm{C}_{6} \mathrm{H}_{6}$. There are two checks on these computations. The small $36 \frac{1}{2}$ peaks are in the ratio 6 to 5 as expected, and the $39 \frac{1}{2}$ peak of $\mathrm{C}_{6} \mathrm{H}_{6}$ containing one $\mathrm{C}^{13}$ atom is of the expected magnitude. From the data of table 3, contributions to the 37,38 , and 39 peaks of both spectra are computed, and the corrected singly charged ion spectra of table 2 are derived. It is to be noted that $\mathrm{C}^{13}$ isotope corrections to the original data have to be recomputed by use of successive approximations to include contributions from doubly charged ions.

\section{Deuteronaphthalenes}

Naphthalene, $\mathrm{C}_{10} \mathrm{H}_{8}$, consists of two benzene rings with two carbon atoms in common, and there is a difference in chemical bonding of the four $\mathrm{H}$ atoms adjacent to the central carbon atoms (the alpha positions) as compared to the other four atoms (beta positions). William G. Dauben, Department of Chemistry, University of California, furnished samples of alpha monodeutero naphthalene and of perdeutero naphthalene. A comparison spectrum of ordinary naphthalene was obtained with an NBS Standard Sample.

In naphthalene, as in benzene and acetylene, one can make accurate measurements of the relative abundance of isotopes at a potential below the appearance potential of the ion $\mathrm{C}_{10} \mathrm{H}_{7}^{+}$. This is over $5 \mathrm{v}$ above the appearance potential of the molecule ion, but there are no published data on this. The $\mathrm{C}_{10} \mathrm{H}_{7} \mathrm{D}$ sample contained $3.30 \pm 0.05$ percent of $\mathrm{C}_{10} \mathrm{H}_{8}$, and the $\mathrm{C}_{10} \mathrm{D}_{8}$ sample contained 13.4 percent of $\mathrm{C}_{10} \mathrm{D}_{7} \mathrm{H}$ and 1 percent of $\mathrm{C}_{10} \mathrm{D}_{6} \mathrm{H}_{2}$. The naphthalenes were of good chemical purity, except for a trace of water. The effect of water is magnified because the vapor pressure of naphthalene is much less than that of water. The naphthalene is adsorbed to some extent in the inlet system, and the different isotopic samples were run on different days after pumping overnight to avoid contamination of one sample by another. These circumstances make experimental errors somewhat greater than for the benzenes.

Table 4 gives in the first three columns the mass spectra of $\mathrm{C}_{10} \mathrm{H}_{8}$ and $\mathrm{C}_{10} \mathrm{H}_{7} \mathrm{D}$ corrected for the $\mathrm{C}^{13}$ contribution, for 3.3 percent of $\mathrm{C}_{10} \mathrm{H}_{8}$ in the monodeutero compound and for doubly charged ions. The a priori probability of removing $\mathrm{H}$ and not $\mathrm{D}$ from $\mathrm{C}_{10} \mathrm{H}_{7} \mathrm{D}$ is $7 / 8$, and $\mathrm{C}_{10} \mathrm{H}_{6} \mathrm{D}^{+}$(mass 128) is almost exactly $7 / 8$ of $\mathrm{C}_{10} \mathrm{H}_{7}^{+}$of $\mathrm{C}_{10} \mathrm{H}_{8}$. The fourth column gives values computed from the $\mathrm{C}_{10} \mathrm{H}_{8}$ spectrum purely on the basis of a priori probabilities of removing $\mathrm{H}$ and not $\mathrm{D}$ and of removing $\mathrm{D}$. The probabilities of removing two to seven $\mathrm{H}$ atoms are $3 / 4,5 / 8,1 / 2,3 / 8,1 / 4$, and $1 / 8$, and the probabilities of removing $\mathrm{D}$ are given by 1 minus these fractions. As in the case of benzene, approximate agreement is found in all cases and agreement well within experimental error in two-thirds of the cases. The fact that the eight $\mathrm{H}$ atoms are not chemically equivalent does not seem to be a complication. 
Doubly charged ions contribute to many of the peaks of mass 64 and less, and some of the corrections are large. Table 5 gives the doubly charged ion spectrum of $\mathrm{C}_{10} \mathrm{H}_{8}$ and $\mathrm{C}_{10} \mathrm{H}_{7} \mathrm{D}$ computed from the observed half-integer peaks in both spectra, assuming the spectra are related purely by a priori probability

TABLE 4. Mass spectra of naphthalenes, $C_{10} \mathrm{H}_{8}$ and $\mathrm{C}_{10} \mathrm{H}_{7} \mathrm{D}$

\begin{tabular}{|c|c|c|c|c|c|c|c|}
\hline \multirow[b]{2}{*}{$m / e$} & \multirow[b]{2}{*}{$\mathrm{C}_{10} \mathrm{H}_{8}$} & \multicolumn{2}{|c|}{$\mathrm{C}_{10} \mathrm{H}_{7} \mathrm{D}$} & \multirow[b]{2}{*}{$m / e$} & \multirow[b]{2}{*}{$\mathrm{C}_{10} \mathrm{H}_{8}$} & \multicolumn{2}{|c|}{$\mathrm{C}_{10} \mathrm{H}_{7} \mathrm{D}$} \\
\hline & & $\begin{array}{c}\text { Ob- } \\
\text { served }\end{array}$ & $\begin{array}{l}\text { Com- } \\
\text { puted }\end{array}$ & & & $\begin{array}{c}\text { Ob- } \\
\text { served }\end{array}$ & $\begin{array}{l}\text { Com- } \\
\text { puted }\end{array}$ \\
\hline 129 & & 100 & 100 & 79 & & 1.68 & 1. 69 \\
\hline 128 & 100 & 8. 59 & 8. 63 & 78 & 2. 25 & $\begin{array}{l}1,08 \\
3.01\end{array}$ & $\begin{array}{l}1.09 \\
2.88\end{array}$ \\
\hline 127 & 9.86 & 5. 10 & 5. 34 & 77 & 3. 72 & 2.73 & $\begin{array}{l}2.88 \\
2.78\end{array}$ \\
\hline 126 & 5.48 & 1.07 & 1. 59 & 73 & 2. 76 & 3. 01 & $\begin{array}{l}3.09 \\
\text { 3. }\end{array}$ \\
\hline 125 & 0.36 & 0.10 & 0.14 & 75 & 4. 55 & 3. 69 & 3. 97 \\
\hline 124 & .01 & .02 & .02 & 74 & 4. 51 & 2. 90 & 3. 45 \\
\hline 123 & .03 & .10 & .07 & 73 & 0.52 & 0.38 & 0.45 \\
\hline $\begin{array}{l}125 \\
122\end{array}$ & .20 & .12 & .16 & 72 & -.... & .03 & 0 \\
\hline 121 & .06 & .03 & .05 & & & & \\
\hline 120 & .05 & .05 & .05 & $\begin{array}{l}66 \\
65\end{array}$ & 0.22 & $\begin{array}{l}0.15 \\
.16\end{array}$ & $\begin{array}{r}0.14 \\
.16\end{array}$ \\
\hline 115 & -...- & .03 & & 64 & ค. 16 & a 1.72 & 1. 53 \\
\hline 114 & $\cdots$ & .09 & .09 & 63 & a 3.86 & a 2.67 & 2. 99 \\
\hline 113 & .15 & .05 & .06 & 62 & × 2.34 & a 1.62 & 1. 90 \\
\hline 112 & 0 & .04 & .02 & 61 & a 1.13 & a 0.78 & 0. 99 \\
\hline 111 & .05 & .06 & .05 & 60 & 0.13 & .11 & 0.13 \\
\hline $\begin{array}{l}110 \\
109\end{array}$ & $\begin{array}{l}.06 \\
.05\end{array}$ & $0^{.04}$ & .04 & 54 & & .12 & .13 \\
\hline 103 & & 4. 63 & 4. 64 & $\begin{array}{l}53 \\
52\end{array}$ & $\begin{array}{l}0.21 \\
1.38\end{array}$ & $\begin{array}{r}.75 \\
2.94\end{array}$ & $\begin{array}{r}.77 \\
2.96\end{array}$ \\
\hline 102 & 6.19 & 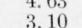 & $\begin{array}{l}4.04 \\
3.12\end{array}$ & 51 & $\begin{array}{r}1.38 \\
\mathrm{x} 6.06\end{array}$ & $\begin{array}{l}\text { × } 5.13 \\
\end{array}$ & $\begin{array}{l}2.90 \\
5.17\end{array}$ \\
\hline 101 & 2. 51 & 1.02 & 1. 16 & 50 & $\begin{array}{l}0.00 \\
\text { × } 5.53\end{array}$ & $\begin{array}{r} \\
\text { a } 3.60\end{array}$ & 4. 21 \\
\hline 100 & 0.44 & 0.37 & 0.43 & 49 & × 0.48 & × 0.32 & 0.42 \\
\hline 99 & .55 & .60 & .63 & 48 & .05 & .04 & .05 \\
\hline 98 & 1,15 & .70 & .89 & & & & \\
\hline 97 & 0.21 & .13 & .18 & $\begin{array}{l}42 \\
41\end{array}$ & .06 & $\begin{array}{l}.03 \\
.10\end{array}$ & $\begin{array}{l}.04 \\
.06\end{array}$ \\
\hline 91 & _..... & .02 & & 40 & .07 & $\begin{array}{l}1.32 \\
\text {. }\end{array}$ & 1. 41 \\
\hline 90 & $-\ldots$ & .43 & .40 & 39 & 3. 68 & 2. 58 & 2. 70 \\
\hline 89 & .64 & .28 & .29 & 38 & \& 1.60 & a 1.17 & 1.34 \\
\hline 88 & .11 & .54 & .54 & 37 & 1. 09 & 0.79 & 0.95 \\
\hline 87 & 1. 27 & .93 & 1. 00 & 36 & 0.09 & .08 & .09 \\
\hline 86 & 0.85 & .57 & 0. 69 & & 03 & & .09 \\
\hline $\begin{array}{l}80 \\
84\end{array}$ & $\begin{array}{l}.38 \\
.09\end{array}$ & $\begin{array}{l}.25 \\
.08\end{array}$ & $\begin{array}{l}.33 \\
.09\end{array}$ & 28 & $\begin{array}{l}.00 \\
.16\end{array}$ & .70 & .73 \\
\hline & & & & $\begin{array}{l}27 \\
26\end{array}$ & $\begin{array}{l}1.74 \\
1.38\end{array}$ & $\begin{array}{l}1.24 \\
0.87\end{array}$ & $\begin{array}{l}\text { 1. } 43 \\
1.05\end{array}$ \\
\hline & & & & $\begin{array}{l}20 \\
25\end{array}$ & $\begin{array}{l}1.50 \\
0.12\end{array}$ & $\begin{array}{r}0.87 \\
.06\end{array}$ & $\begin{array}{l}1.05 \\
0.11\end{array}$ \\
\hline
\end{tabular}

\& Values corrected for doubly charged ions. considerations. This is probably not accurately true, as two peaks computed on another basis give slightly different values. The 64 peak of $\mathrm{C}_{10} \mathrm{H}_{8}$ is mostly $\mathrm{C}_{10} \mathrm{H}_{8}^{++}$and is definitely smaller than $\mathrm{C}_{10} \mathrm{H}_{7} \mathrm{D}^{++}$. The $\mathrm{C}_{8} \mathrm{H}_{6}^{++}$peak of $\mathrm{C}_{10} \mathrm{H}_{8}$ is computed from the $\mathrm{C}_{13}$ isotope peak of this ion and again is somewhat less than $\mathrm{C}_{8} \mathrm{H}_{5} \mathrm{D}^{++}+\mathrm{C}_{8} \mathrm{H}_{6}^{++}$of the deutero compound. Table 5 omits some small peaks of less than 0.1 .

The rather large amount of $\mathrm{C}_{10} \mathrm{D}_{7} \mathrm{H}$ in the $\mathrm{C}_{10} \mathrm{D}_{8}$ compound makes computation of the $\mathrm{C}_{10} \mathrm{D}_{8}$ spectrum less accurate than the data for the other compounds, but the results of table 4 justify the assumption that both the $\mathrm{C}_{10} \mathrm{D}_{7} \mathrm{H}$ spectrum and the $\mathrm{C}_{10} \mathrm{D}_{8}$ spectrum can be computed from the mixture spectrum on the basis of a priori probability considerations. As these assumptions are only approximately true, we

TABLE 5. Doubly charged ions of $\mathrm{C}_{10} \mathrm{H}_{8}$ and $\mathrm{C}_{10} \mathrm{H}_{7} \mathrm{D}^{\text {a }}$

\begin{tabular}{|c|c|c|c|c|c|}
\hline \multicolumn{2}{|c|}{$\mathrm{C}_{10} \mathrm{H}_{8}$} & \multicolumn{4}{|c|}{$\mathrm{C}_{10} \mathrm{H}_{7} \mathrm{D}$} \\
\hline Ion & $\begin{array}{l}\text { Relative } \\
\text { intensity }\end{array}$ & Ion & $\begin{array}{l}\text { Relative } \\
\text { intensity }\end{array}$ & Ion & $\begin{array}{l}\text { Relative } \\
\text { intensity }\end{array}$ \\
\hline $\begin{array}{l}\mathrm{C}_{10} \mathrm{H}_{8} \ldots \\
\mathrm{C}_{10} \mathrm{H}_{7} \\
\mathrm{C}_{10} \mathrm{H}_{6} \ldots \\
\mathrm{C}_{10} \mathrm{H}_{5 \ldots} \\
\mathrm{C}_{10} \mathrm{H}_{4 \ldots} \\
\mathrm{C}_{10} \mathrm{H}_{3} \ldots \\
\mathrm{C}_{10} \mathrm{H}_{2 \ldots}\end{array}$ & $\begin{array}{c}\mathrm{b} 10.6 \\
0.95 \\
(3.53) \\
0.20 \\
(.20) \\
.08 \\
(.40)\end{array}$ & $\begin{array}{l}\mathrm{C}_{10} \mathrm{H}_{7} \mathrm{D} \\
\mathrm{C}_{10} \mathrm{H}_{6} \mathrm{D} \\
\mathrm{C}_{10} \mathrm{H}_{5} \mathrm{D} \\
\mathrm{C}_{10} \mathrm{H}_{4} \mathrm{D} \\
\mathrm{C}_{10} \mathrm{H}_{3} \mathrm{D} \\
\mathrm{C}_{10} \mathrm{H}_{2} \mathrm{D} \\
\mathrm{C}_{10} \mathrm{HD}\end{array}$ & $\begin{array}{c}12.0 \\
(0.83) \\
2.65 \\
(0.13) \\
.10 \\
(.03) \\
.10\end{array}$ & $\begin{array}{l}\mathrm{C}_{10} \mathrm{H}_{7} \ldots \ldots \\
\mathrm{C}_{10} \mathrm{H}_{6 \ldots} \ldots \\
\mathrm{C}_{10} \mathrm{H}_{5 \ldots} \\
\mathrm{C}_{10} \mathrm{H}_{4} \ldots \\
\mathrm{C}_{10} \mathrm{H}_{3} \ldots \\
\mathrm{C}_{10} \mathrm{H}_{2 \ldots}\end{array}$ & $\begin{array}{r}(0.12) \\
(.88) \\
(.07) \\
(.10) \\
(.05) \\
(.30)\end{array}$ \\
\hline $\begin{array}{l}\mathrm{C}_{8} \mathrm{H}_{6} \ldots \ldots \\
\mathrm{C}_{8} \mathrm{H}_{5} \ldots \\
\mathrm{C}_{8} \mathrm{H}_{4} \ldots \\
\mathrm{C}_{8} \mathrm{H}_{3} \ldots \\
\mathrm{C}_{8} \mathrm{H}_{2} \ldots\end{array}$ & $\begin{array}{c}\circ 6.23 \\
0.09 \\
(.84) \\
.24 \\
(.24)\end{array}$ & $\begin{array}{l}\mathrm{C}_{8} \mathrm{H}_{5} \mathrm{D} \\
\mathrm{C}_{8} \mathrm{H}_{4} \mathrm{D} \\
\mathrm{C}_{8} \mathrm{H}_{3} \mathrm{D} \\
\mathrm{C}_{8} \mathrm{H}_{2} \mathrm{D} \\
\mathrm{C} 8 \mathrm{H}_{8} \mathrm{D}\end{array}$ & $\begin{array}{c}5.16 \\
(0.06) \\
.42 \\
(.09) \\
.06\end{array}$ & $\begin{array}{l}\mathrm{C}_{8} \mathrm{H}_{6} \\
\mathrm{C}_{8} \mathrm{H}_{5} \\
\mathrm{C}_{8} \mathrm{H}_{4} \\
\mathrm{C}_{8} \mathrm{H}_{3} \\
\mathrm{C}_{8} \mathrm{H}_{2}\end{array}$ & $\begin{array}{r}(1.72) \\
(0.03) \\
(.42) \\
(.15) \\
(.18)\end{array}$ \\
\hline $\mathrm{C}_{6} \mathrm{H}_{4 \ldots} \ldots$ & $(.10)$ & $\mathrm{C}_{6} \mathrm{H}_{3} \mathrm{D}$ & .05 & $\mathrm{C}_{6} \mathrm{H}_{4} \ldots \ldots$ & $(.05)$ \\
\hline
\end{tabular}

a Values in parentheses are computed on the basis of a priori probabilities from the other values.

b Computed from the observed peak at mass 64 , with a small correction for $\mathrm{C}_{5} \mathrm{H}_{4}^{+}$estimated on the basis of $\mathrm{C}_{5} \mathrm{H}_{3} \mathrm{D}^{+}$of $\mathrm{C}_{10} \mathrm{H}_{7} \mathrm{D}$.

- Computed on the basis of the $\mathrm{C}^{13}$ isotope peak of $\mathrm{C}_{8} \mathrm{H}_{6}^{++}$

TABLE 6. Partial mass spectra of $\mathrm{C}_{10} \mathrm{D}_{8}$ and $\mathrm{C}_{10} \mathrm{D}_{7} \mathrm{H}$

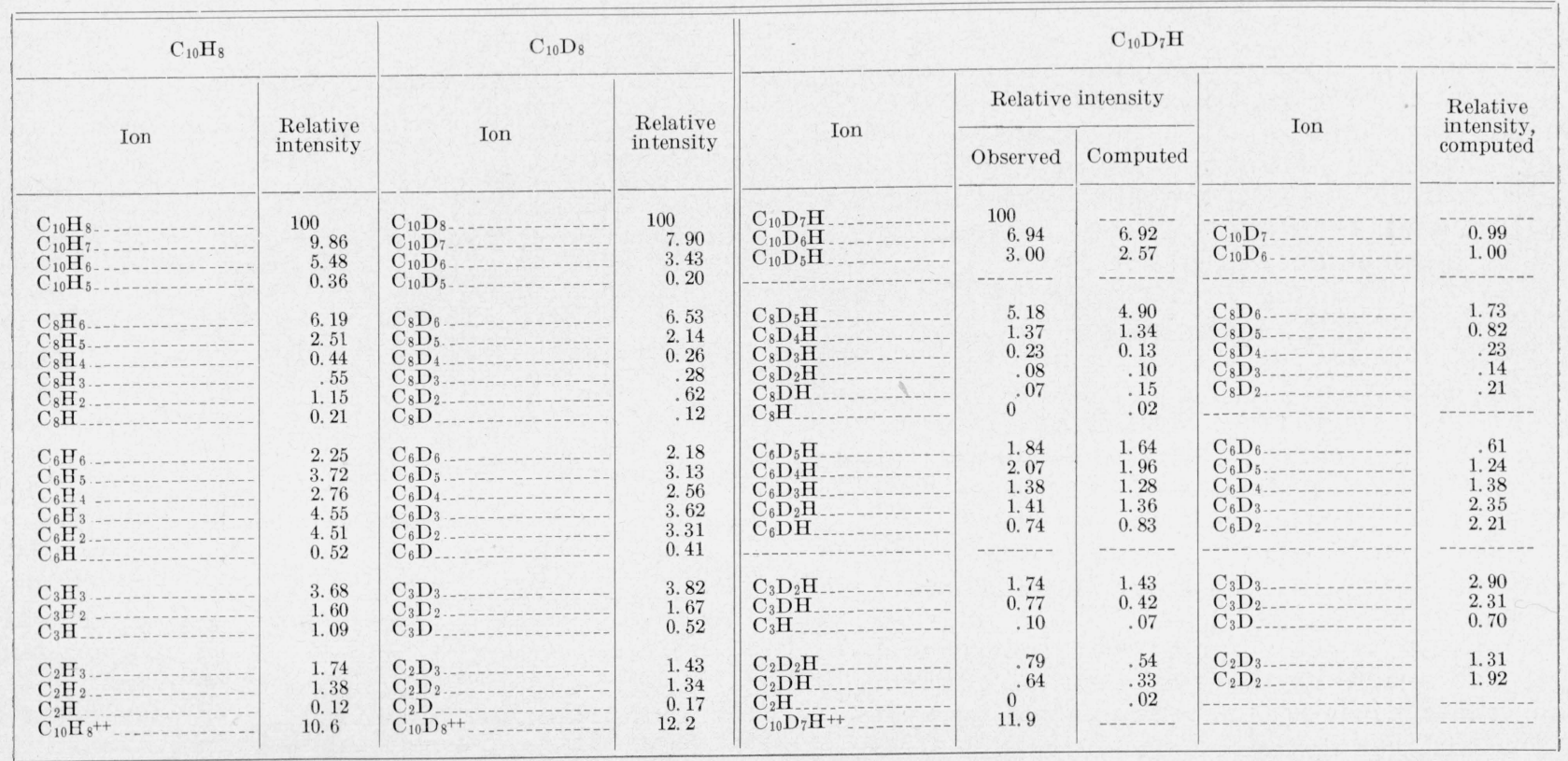


can disregard the contribution of 1 percent of $\mathrm{C}_{10} \mathrm{D}_{6} \mathrm{H}_{2}$ to the spectrum. In the $\mathrm{C}_{10} \mathrm{D}_{8}$ spectrum, only peaks of even mass number will appear after correction for $\mathrm{C}^{13}$ and doubly charged ions. The odd-integer peaks come from the $\mathrm{C}_{10} \mathrm{D}_{7} \mathrm{H}$ fragment ions that contain $\mathrm{H}$ and from doubly charged ions, whereas half-integer peaks come only from doubly charged ions containing $H$. These considerations should permit computation of the singly and doubly charged spectra of both compounds. In practice, however, the half-integer peaks are very small, and computations of doubly charged spectra are inaccurate. For this reason, data on doubly charged fragment ions and on singly charged ions containing five or four carbon atoms are omitted. Also, for brevity, the small peaks containing seven carbon ions are omitted from table 6 .

In table 6 ions are identified by the chemical formulas to facilitate comparison of corresponding ions. Columns 1 and 2 repeat from table 4 the $\mathrm{C}_{10} \mathrm{H}_{8}$ spectrum. Columns 3 and 4 give the observed $\mathrm{C}_{10} \mathrm{D}_{8}$ spectrum after correction for the contribution of $\mathrm{C}_{10} \mathrm{D}_{7} \mathrm{H}$ to this spectrum. Columns 5 and 6 give the observed $\mathrm{C}_{10} \mathrm{D}_{7} \mathrm{H}$ peaks of ions containing $\mathrm{H}$, normalized to make the $\mathrm{C}_{10} \mathrm{D}_{7} \mathrm{H}$ peak 100 (actually it is $15.7 \%$ of $\mathrm{C}_{10} \mathrm{D}_{8}$ ). Column 7 gives values of these peaks computed from the $\mathrm{C}_{10} \mathrm{D}_{8}$ spectrum, and columns 8 and 9 give the computed values of the ions containing $\mathrm{D}$ but not $\mathrm{H}$.

The procedure in making computations can be illustrated by the second line of data in table 6 . The observed $\mathrm{C}_{10} \mathrm{D}_{6} \mathrm{H}^{+}$peak is 6.94 relative to $\mathrm{C}_{10} \mathrm{D}_{7} \mathrm{H}^{+}$, and $\mathrm{C}_{10} \mathrm{D}_{7}{ }^{+}$of $\mathrm{C}_{10} \mathrm{D}_{7} \mathrm{H}$ will be $1 / 7$ of this, or 0.99 . 15.7 percent of this, or 0.16 , is to be subtracted from the 134 peak to give $\mathrm{C}_{10} \mathrm{D}_{7}{ }^{+}$of $\mathrm{C}_{10} \mathrm{D}_{8}$ as 7.90 . The computed value of $\mathrm{C}_{10} \mathrm{D}_{6} \mathrm{H}$ is $7 / 8$ of this, or 6.92 , in accurate agreement with the observed value 6.94. Table 6 includes the doubly charged molecule ions. $\mathrm{C}_{10} \mathrm{D}_{8}{ }^{++}$is computed on the basis of the 68 peak, with a small correction for $\mathrm{C}_{5} \mathrm{D}_{4}{ }^{+}$. $\mathrm{C}_{5} \mathrm{D}_{4}^{+}$is assumed to be equal to $\mathrm{C}_{5} \mathrm{H}_{3} \mathrm{D}^{+}$of $\mathrm{C}_{10} \mathrm{H}_{7} \mathrm{D}$ (table 4 ), or 0.16 .

In general, observed and computed values of columns 6 and 7 are not accurately equal, but experimental uncertainties are large because $\mathrm{C}_{10} \mathrm{D}_{7} \mathrm{H}$ is only 16 percent of $\mathrm{C}_{10} \mathrm{D}_{8}$. The difference between $\mathrm{C}_{10} \mathrm{H}_{8}{ }^{++}$and $\mathrm{C}_{10} \mathrm{D}_{8}{ }^{++}$is probably a real difference. $\mathrm{C}_{10} \mathrm{D}_{8}^{++}, \mathrm{C}_{10} \mathrm{D}_{7} \mathrm{H}^{++}$, and $\mathrm{C}_{10} \mathrm{H}_{7} \mathrm{D}^{++}$are all equal to 12.0 within experimental error.

\section{Conclusion}

The spectrum of $\mathrm{C}_{2} \mathrm{HD}$ resembles spectra of other hydrocarbons containing both $H$ and $D$ that have been studied previously, in that it shows a strong selective effect for removing $H$ in preference to $D$. In $\mathrm{C}_{2} \mathrm{HD}$ the probability of removing $\mathrm{H}$ as compared with the probability of removing $\mathrm{D}$ is 1.92 . In the deuteromethanes the ratios are 2.6 times the $a$ priori probability for $\mathrm{CH}_{3} \mathrm{D}, 2.5$ for $\mathrm{CH}_{2} \mathrm{D}_{2}$, and 1.6 for $\mathrm{CHD}_{3}$. The result obtained with acetylene shows that this selectivity does not depend on having $\mathrm{H}$ and $\mathrm{D}$ atoms on the same carbon atom.
It is surprising to find that this selective effect is absent or very small in $\mathrm{C}_{6} \mathrm{H}_{5} \mathrm{D}$ and $\mathrm{C}_{10} \mathrm{H}_{7} \mathrm{D}$. The probability of removing $\mathrm{H}$ and not $\mathrm{D}$ from these molecules is almost exactly equal to the a priori probabilities, and the complete spectra of $\mathrm{C}_{6} \mathrm{H}_{5} \mathrm{D}$ and $\mathrm{C}_{10} \mathrm{H}_{7} \mathrm{D}$ can be computed from $\mathrm{C}_{6} \mathrm{H}_{6}$ and $\mathrm{C}_{10} \mathrm{H}_{8}$ spectra. The agreement with experiment is not perfect, but the method gives a good approximation. The results justify computation of the spectra of $\mathrm{C}_{10} \mathrm{D}_{8}$ and $\mathrm{C}_{10} \mathrm{D}_{7} \mathrm{H}$ from a mixture of 86 percent of the first compound and 13 percent of the second compound. In most hydrocarbons there is no basis for making such a computation. There is a significant difference between corresponding mass peaks of $\mathrm{C}_{10} \mathrm{H}_{8}$ and $\mathrm{C}_{10} \mathrm{D}_{8}$, which is comparable with the difference between $\mathrm{C}_{2} \mathrm{H}_{2}$ and $\mathrm{C}_{2} \mathrm{D}_{2}$, and $\mathrm{CH}_{4}$ and $\mathrm{CD}_{4}[3]$, and $\mathrm{C}_{2} \mathrm{H}_{6}$ and $\mathrm{C}_{2} \mathrm{D}_{6}$ [7]. The probability of losing $\mathrm{D}$ atoms is less than that of losing $\mathrm{H}$ atoms, but fragment ions involving breaking of $\mathrm{C}-\mathrm{C}$ bonds may be either greater or less in the deutero compound.

Possibly the absence of a selective isotope effect in benzene and napthalene is correlated with the evidence that there seems to be a complete rearrangement of atoms in any ionization process involving a benzene ring. This is illustrated by the mass spectra of the four monodeuteromethyl benzene molecules that have been published in the API catalog of mass spectral data [11]. There is no significant difference between the molecules with D in the three different ring positions. However, the methylbenzene with $\mathrm{D}$ in the methyl radical differs from the other compounds in a manner consistent with its structure, and $\mathrm{CH}_{2} \mathrm{D}^{+}$is large and $\mathrm{C}_{6} \mathrm{H}_{4} \mathrm{D}^{+}$ small or absent when $\mathrm{D}$ is in the methyl group. It is also true that when two or more methyl radicals are attached to the benzene ring their relative positions make very little difference in the resulting mass spectra of the isomeric molecules. This is not an explanation of the nearly random loss of $\mathrm{H}$ and D from aromatic rings, but only a suggestive correlation.

\section{References}

[1] D. P. Stevenson and C. D. Wagner, J. Chem. Phys. 19, 11 (1951)

[2] J. Turkevich, et al., J. Am. Chem. Soc. 70, 2638 (1948).

[3] V. H. Dibeler and F. L. Mohler, J. Research NBS 45, 441 (1950) RP2155.

[4] C. D. Wagner and D. P. Stevenson, J. Am. Chem. Soc. 7\%, $5612(1950)$

[5] F. L. Mohler and V. H. Dibeler, Phys. Rev. 72, 158 (1947) Abstract.

[6] P. Kusch, A. Hustrulid, and J. T. Tate, Phys. Rev. 52, 843 (1937).

[7] V. H. Dibeler, F. L. Mohler, and L. M. Williamson, J. Research NBS 44, 489 (1950) RP2095.

[8] A. Hustrulid, P. Kusch, and J. T. Tate, Phys. Rev. 54, 1037 (1938).

[9] Catalog of Mass Spectral Data No. 438, API Research Project 44.

[10] Catalog of Mass Spectral Data No. 414, API Research Project 44.

[11] Catalog of Mass Spectral Data No. 355 to 358, API Research Project 44.

Washington, November 28, 1951. 